\title{
China and Russia - A study on Cooperation, Competition and Distrust
}

\author{
Märta Carlsson, Susanne Oxenstierna \& Mikael Weissmann \\ Stockholm: FOI 2015 \\ 99 sider. ISSN 1650-1942
}

Anmeldt av Tom Røseth [forsker, Institutt for forsvarsstudier (IFS), tom.roseth@ ifs.mil.no]

Forholdet mellom Russland og Kina er viktig for å forstå dynamikken i global sikkerhetspolitikk, og graden av samarbeid mellom disse har implikasjoner for Europa og Norden. Washington har det siste tiåret hatt et økende fokus på Asia, med noe mindre sikkerhetspolitisk interesse for Russland og Europa - inntil Ukraina-konflikten i 2014. Europa har hatt økonomiske og politiske problemer siden den økonomiske krisen i 2008-2010. Russland hadde en sterk økonomisk vekst fra 2000 til 2008, og har siden gjennomført større reformer og modernisering av forsvaret tross lav økonomisk vekst. Med en voksende militær verktøykasse har Russland definert sine interesser i nærområdet og demonstrert en lavere terskel for militær maktanvendelse. En grunnleggende faktor i utenrikspolitikken for både Russland og Kina er et mål om å underbygge intern stabilitet, men i motsetning til russerne har kineserne valgt en indirekte måte å fremme sine stormaktambisjoner på. Beijing er seg bevisst at en konflikt med Europa eller USA vil skade økonomisk utvikling og derav kunne true regimestabiliteten.

Overnevnte danner noe av bakteppet for FOIs velskrevne rapport om forholdet mellom Russland og Kina. Det er tydelig at forfatterne har lent seg henimot førende realismeorientert sekundærlitteratur, samt supplert og korrigert med intervjuer i både Moskva og Beijing. De har således fått frem et ordentlig bilde av mulighetene og spesielt begrensningene i det bilaterale forholdet. Strukturen i rapporten er god, og sentrale temaer som utenrikspolitikk, økonomi, stillehavsområdet og Sentral-Asia vektlegges. Rapporten maler ofte med bred pensel, men nettopp å gi en oppdatert sammenfatning er også hensikten. Målgruppen er forskere, studenter og beslutningstagere som ønsker en konsis oppdatering på forholdet mellom Russland og Kina - og hva dette forholdet har å si for global sikkerhetspolitikk. Forfatterne har komplementerende bakgrunn og utfyller hverandre godt, noe som gir rapporten et troverdig helhetsbilde. Akademiske arbeider om dette temaet er oftest utført av Russlandskjennere og er dermed vektet fra Moskva. Denne rapporten har en klar styrke i at den formidler relasjonen likeverdig sett fra Beijing, noe som gir en bedre balanse i analysene. Forfatterne har også fått med seg de siste års utvikling med Ukrainakonflikten og den forverrede relasjonen mellom Russland og Vesten. 
Forfatterne Carlsson, Oxenstierna og Weissmann slår tidlig fast at forholdet mellom Russland og Kina bør forstås som en flyktig allianse bestående av to misfornøyde stater som veksler på å samarbeide og å konkurrere. I rapporten fokuseres det mest på begrensningene i relasjonen og at forholdet er «riddled with competition and distrust. Only on certain issues does cooperation exist» (s. 18). Gitt de senere års forbedring i det bilaterale forholdet, med økt samarbeid blant annen innenfor energi og forsvar samt enighet rundt en rekke internasjonale saker, kan en slik konklusjon synes å se glasset som mer halvtomt enn halvfullt. Særlig etter Ukraina-konflikten er Russland mer prisgitt relasjonen til Kina enn tidligere, noe som demonstreres gjennom en mengde symbolpolitikk med tilhørende økonomiske og politiske ambisjoner, men også gjennom reelle russisk-kinesiske avtaler. Et eksempel er signeringen nå i november 2015 om å selge 24 avanserte SU-35-jagerfly til Kina. Selv om det er interessemotsetninger og utfordringer i forholdet mellom disse stormaktene, er det fortsatt en pågående prosess hvor forbindelsene forbedres både i dybde og bredde, og det er en utvikling en kan vente vil fortsette. Dette fordi landene på en rekke områder tross alt har en felles interesse av et godt forhold. Det strategisk åpenbare er at begge ønsker ryggen fri for å fokusere på andre problemområder, samtidig som de trenger hverandres støtte i konflikter som vil påkalle sikkerhetsrådsmøter i FN.

Likevel, forfatterne tegner et realistisk bilde av forholdet mellom Russland og Kina. For det finnes mange myter og alarmistiske overdrivelser om en militærallianse som vil utfordre den vestlige verdensorden. Lesere som trodde at tilnærmelsen mellom Kina og Russland beveger seg mot en militær allianse eller en koordinert samlet kraft mot Vesten, vil bli ledet ut av villfarelse. Det er få utsikter for at relasjonen går over til et nivå der den globale verdensordenen blir utfordret og overtatt av et tospann bestående av et stadig økonomisk voksende Kina understøttet av et militarisert Russland rikt på naturressurser (se Douglas E. Schoen \& Melik Kaylan, The Russia-China Axis: The New Cold War and America's Crisis of Leadership. New York: Encounter Books, 2014). En kjølig analyse er nødvendig for ikke å overdrive betydningen av tilnærmingen mellom Russland og Kina, samtidig som det ikke bør fornektes at deres bilaterale relasjoner er under stadig utvikling. Rapportens viktigste bidrag er nettopp å gi en edruelig og nøktern analyse av forholdet mellom Russland og Kina, samtidig som den tar for seg implikasjoner av Ukraina-konflikten.

FOI-rapporten peker på iboende begrensninger, og legger vekt på spesielt USAs rolle. Dette er samme ankepunkt som Bobo Lo kvitterer for, med sin toneangivende bok Axis of Convenience (Washington, D.C.: Brookings Institution Press, 2008), som forfatterne refererer til en rekke ganger. Russland og Kina definerer seg selv og sin bilaterale relasjon først og fremst i forhold til USA, tredjeparten $\mathrm{i}$ 《makttriangelet». Kina vil ikke ofre relasjonen til USA over Russland, til det er den økonomiske gjensidige avhengigheten for stor. Både Russland og Kina blir imidlertid sikkerhetspolitisk utfordret av USAs planer om rakettskjold i Europa og Asia, NATO-utvidelse i Europa, og Washingtons «pivot to Asia» med økt spenning i Sør-Kina-havet. Det er en potensiell svakhet i Russland-Kina-forholdet at partene er svært sensitive overfor endringer i nettopp den andres relasjon til USA. Dersom enten Beijing eller Moskva dramatisk forbedrer sitt forhold til USA, vil den andre stå alene. På den annen side 
styrker USA-faktoren forholdet og er en hovedgrunn til at Beijing og Moskva fremover vil søke et bredere og dypere samarbeid, dog med de begrensninger rapporten gjør rede for.

Forfatterne gir godt belegg for å hevde at relasjonen ikke vil bli en formalisert militærallianse. De har valgt en noe restriktiv tolkning av potensiell dybde i RusslandKina-forholdet. Deltakelsen i Syria-konflikten vil kunne føre Moskva nærmere, eller mer sannsynlig ytterligere distansere Russland fra USA og Europa, og således innvirke på det russiske behovet for å lene seg henimot Kina. Rapporten er på under hundre sider og vel verdt lesingen. 